\title{
Is Brachytherapy Feasible After Head and Neck Cancer Reconstructive Surgery? Preliminary Report
}

\author{
Anna Bartochowska ${ }^{1}$ (D) Jacek Banaszewski ${ }^{1}$ (D) $\cdot$ Małgorzata Wierzbicka ${ }^{1,2}$ (D)
}

Received: 26 March 2020 / Accepted: 14 May 2020 / Published online: 25 May 2020

(C) The Author(s) 2020

\begin{abstract}
The purpose of the study was to evaluate the influence of interstitial postoperative brachytherapy for the vitality and quality of flaps used for reconstruction of tissue defects after head and neck cancer salvage resection. We aimed at presenting six consecutive patients with recurrent squamous cell carcinoma in head and neck region who underwent salvage surgery and tissue reconstruction with a regional or free flap followed by brachytherapy. Reconstruction was performed with a free radial forearm flap in 2 cases, with a free thigh flap in 2 cases, and with a myocutaneous lateral upper arm flap in the next 2 cases. In all patients, pulsed-dose-rate brachytherapy was used with a median value of $0.7 \mathrm{~Gy}$ (range $0.6-0.8 \mathrm{~Gy}$ ) per pulse and a median total dose of $20 \mathrm{~Gy}$ (range 20-40 Gy). In the analyzed group, there were no serious wound and flap complications after brachytherapy. In one case, peripheral skin necrosis was noticed. No revision surgery was needed but only surgical debridement of the necrotic margins. All wounds healed within 14 days after surgery as well as donor sites which healed within 4 weeks. Based upon our data, pulseddose-rate brachytherapy seems to be a safe option that can be performed at the site of reconstruction in immediate postoperative period with minimal wound complications and with no impact on flap survival. Further clinical study based on larger patient series is needed to present statistically proven results.
\end{abstract}

Keywords PDR brachytherapy $\cdot$ Recurrent head and neck cancers $\cdot$ Free flap $\cdot$ Pedicle flap

\section{Introduction}

The management of recurrent head and neck cancers is a challenge and always requires individualized therapy planned by a team of surgeons, oncologists, and radiotherapists. Unfortunately, curative options for this group of patients are very often limited. In most cases, salvage approach includes large resections followed by sophisticated microsurgical reconstructions [1-4]. The difficulty to assess sufficient clear margins together with the inability to re-treat the tumor bed

Electronic supplementary material The online version of this article (https://doi.org/10.1007/s12262-020-02398-2) contains supplementary material, which is available to authorized users.

Anna Bartochowska

annabartochowska@gmail.com

1 Department of Otolaryngology, Head and Neck Surgery, Poznan University of Medical Sciences, 49 Przybyszewskiego Street, 60-355 Poznań, Poland

2 Institute of Human Genetics, Polish Academy of Sciences, Poznań, Poland with external beam radiotherapy (EBRT) due to the excessive morbidity and complications rates brings the need to use other options. Brachytherapy (BT) provides specific, intensive local irradiation of the oncologically unsafe regions in the immediate postoperative period, allowing protection of surrounding structures and preserving organ functions [5, 6]. The question arises whether it can be associated with delayed wound healing and its breakdown. Flap necrosis due to vascular coagulation and fibrosis creates an additional strongly documented risk for the patient, and all factors that can increase it should be considered [7-9].

The aim of the study was to evaluate the influence of interstitial postoperative brachytherapy for the vitality and quality of flaps used for reconstruction of tissue defects after head and neck cancer salvage resection.

\section{Patients and Methods}

Six consecutive patients with recurrent squamous cell carcinoma in head and neck region who underwent salvage surgery and tissue reconstruction with a regional or free flap followed by BT were included into the study. In all cases, recurrence 
appeared in previously irradiated region. Historical patients' records were analyzed (Table 1).

Four patients were men, while two were women, and mean age was 56 years (range $38-65$ ). Two patients underwent total laryngectomy with partial resection of the hypopharynx and/ or esophagus, two patients had a salvage surgery of the stomal recurrence, one patient had recurrent cancer of the oral cavity and pharynx resected, while one patient was operated due to

Table 1 Patients characteristics, methods of treatment, and wound/flap complications

\begin{tabular}{|c|c|c|c|c|c|c|}
\hline & Patient 1 & Patient 2 & Patient 3 & Patient 4 & Patient 5 & Patient 6 \\
\hline Sex & Man & Man & Woman & Man & Man & Woman \\
\hline Age & 58 & 59 & 38 & 62 & 53 & 65 \\
\hline Comorbidities & $\begin{array}{l}\text { Ischemic heart disease, } \\
\text { hypertension }\end{array}$ & - & Diabetes & Hypertension & - & $\begin{array}{l}\text { Chronic myeloid } \\
\text { leukemia }\end{array}$ \\
\hline $\begin{array}{l}\text { Previous } \\
\text { oncological } \\
\text { treatment }\end{array}$ & $\begin{array}{l}\text { Primary RChT (full } \\
\text { dose of EBRT) due } \\
\text { to laryngeal cancer } \\
\text { (SCC) }\end{array}$ & $\begin{array}{l}\text { Primary RChT } \\
\text { (full dose of } \\
\text { EBRT) due to } \\
\text { laryngeal cancer } \\
\text { (SCC) }\end{array}$ & $\begin{array}{l}\text { Total laryngectomy, } \\
\text { cervical } \\
\text { lymphadenectomy + } \\
\text { RChT (full dose of } \\
\text { EBRT) (SCC) }\end{array}$ & $\begin{array}{l}\text { Total } \\
\text { laryngectomy, } \\
\text { cervical } \\
\text { lymphadenecto- } \\
\text { my + RChT (full } \\
\text { dose of EBRT) } \\
\text { (SCC) }\end{array}$ & $\begin{array}{l}\text { Primary RChT } \\
\text { (full dose of } \\
\text { EBRT) due to } \\
\text { the cancer of } \\
\text { the base of the } \\
\text { tongue (SCC) }\end{array}$ & $\begin{array}{l}\text { Primary RT (full } \\
\text { dose of } \\
\text { EBRT) due to } \\
\text { the neck } \\
\text { tumor (CUP } \\
\text { syndrome; } \\
\text { SCC) }\end{array}$ \\
\hline $\begin{array}{l}\text { Disease-free } \\
\text { duration }\end{array}$ & 16 months & 18 months & 24 months & 13 months & 11 months & 4 months \\
\hline Recurrence & rT4N1M0 & rT4N1M0 & rT4N1M0 & rT4N0M0 & tT4N2M0 & rTxN3M0 \\
\hline $\begin{array}{l}\text { characteris- } \\
\text { tics }\end{array}$ & $\begin{array}{l}\text { Advanced recurrence } \\
\text { in the larynx with } \\
\text { the infiltration of the } \\
\text { hypopharynx and } \\
\text { esophagus, neck } \\
\text { metastases }\end{array}$ & $\begin{array}{l}\text { Advanced } \\
\text { recurrence in the } \\
\text { larynx with the } \\
\text { infiltration of the } \\
\text { esophagus, neck } \\
\text { metastases }\end{array}$ & $\begin{array}{l}\text { Recurrence in the stomal } \\
\text { region, neck metastases }\end{array}$ & $\begin{array}{l}\text { Recurrence in the } \\
\text { stomal region }\end{array}$ & $\begin{array}{l}\text { Recurrence } \\
\text { localized in the } \\
\text { tongue, } \\
\text { infiltrating } \\
\text { palatine tonsil, } \\
\text { neck metastases }\end{array}$ & $\begin{array}{l}\text { Advanced neck } \\
\text { nodal } \\
\text { recurrence in } \\
\text { regions IIa, } \\
\text { IIb, and V }\end{array}$ \\
\hline $\begin{array}{l}\text { Salvage } \\
\quad \text { surgery } \\
\text {-Type } \\
\text {-Flap }\end{array}$ & $\begin{array}{l}\text {-Total laryngectomy } \\
\text { with partial resection } \\
\text { of the hypopharynx } \\
\text { and esophagus, } \\
\text { lymphadenectomy } \\
\text {-Free thigh flap }\end{array}$ & $\begin{array}{l}\text {-Total } \\
\text { laryngectomy } \\
\text { with partial } \\
\text { resection of the } \\
\text { esophagus, } \\
\text { lymphadenecto- } \\
\text { my } \\
\text {-Free thigh flap }\end{array}$ & $\begin{array}{l}\text {-Salvage surgery of the } \\
\text { stomal recurrence, } \\
\text { lymphadenectomy } \\
\text {-Free radial forearm flap }\end{array}$ & $\begin{array}{l}\text {-Salvage surgery } \\
\text { of the stomal } \\
\text { recurrence } \\
\text {-Myocutaneous } \\
\text { lateral upper } \\
\text { arm flap }\end{array}$ & $\begin{array}{l}\text {-Resection of the } \\
\text { recurrent cancer } \\
\text { of the oral } \\
\text { cavity and } \\
\text { pharynx, } \\
\text { lymphadenecto- } \\
\text { my } \\
\text {-Free radial } \\
\text { forearm flap }\end{array}$ & $\begin{array}{l}\text {-Advanced neck } \\
\text { nodal } \\
\text { recurrence } \\
\text { resection } \\
\text {-Myocutaneous } \\
\text { lateral upper } \\
\text { arm flap }\end{array}$ \\
\hline BT-Method & -PDR & -PDR & -PDR & -PDR & -PDR & -PDR \\
\hline -Localization & -Neck & -Stoma & -Stoma & -Stoma & -Neck & -Neck \\
\hline $\begin{array}{l}\text { of } \\
\text { applicators } \\
\text {-Number of } \\
\text { catheters }\end{array}$ & -5 & -3 & -4 & -4 & -5 & -3 \\
\hline $\begin{array}{l}\text { Flap perfusion } \\
\text { (tissue color, } \\
\text { turgor, } \\
\text { temperatur- } \\
\text { e, capillary } \\
\text { refill, } \\
\text { bleeding) }\end{array}$ & $\begin{array}{l}12 \text { h after surgery } \\
\text { abnormal flap } \\
\text { perfusion (bluish } \\
\text { color, high turgor, } \\
\text { rapid refill, dark } \\
\text { bleeding) } \\
\text { No abnormalities after } \\
\text { revision surgery, } \\
\text { after BT and in the } \\
\text { follow-up period }\end{array}$ & No abnormalities & $\begin{array}{l}7 \text { days after surgery and } \\
2 \text { days after BT } \\
\text { abnormal perfusion in } \\
\text { peripheral parts of the } \\
\text { flap (dark color, no } \\
\text { refill, no bleeding) }\end{array}$ & No abnormalities & No abnormalities & No abnormalities \\
\hline Complications & $\begin{array}{l}\text { Venous thrombosis } \\
\text { (before BT) }\end{array}$ & - & Peripheral skin necrosis & - & - & - \\
\hline $\begin{array}{l}\text { Management } \\
\text { of the } \\
\text { complica- } \\
\text { tions }\end{array}$ & $\begin{array}{l}\text { New venous } \\
\text { anastomosis creation }\end{array}$ & - & $\begin{array}{l}\text { Surgical debridement of } \\
\text { the necrotic margins }\end{array}$ & - & - & - \\
\hline
\end{tabular}

$R C h T$ radiochemotherapy, EBRT external beam radiotherapy, $S C C$ squamous cell carcinoma, $C U P$ carcinoma of unknown primary, $B T$ brachytherapy, $P D R$ pulsed-dose-rate 
the advanced neck nodal recurrence. Reconstruction was performed with a free radial forearm flap in 2 cases, with a free thigh flap in 2 cases and with a myocutaneous lateral upper arm flap in the next 2 cases (Table 1). BT catheters were implanted parallelly with a constant distance of $1-1.5 \mathrm{~cm}$ to achieve homogenous dose distribution in the regions of unsafe margins: around the stoma in 3 cases, in the II-IV regions of the neck in the following 3 cases, and then all were sealed with the flaps. An average of 4 (3-5) catheters was inserted. All patients were given antibiotics preventively. The target volume was defined postoperatively, just before BT, with the use of CT and MRI scans. Standard geometric optimization was used to plan the treatment, while prescription dose was based on the modified Paris dosimetry scheme. All parameters were determined by the tumor location and the proximity to adjacent critical organs. BT started 3-7 days after surgery. In all patients, pulsed-dose-rate BT (PDR-BT) was used with a median value of 0.7 Gy (range $0.6-0.8 \mathrm{~Gy}$ ) per pulse and a median total dose of 20 Gy (range: $20-40$ Gy) delivered in 20-24 $\mathrm{h}$ with a time interval of $1 \mathrm{~h}$ between the pulses. In the treatment, the following equipment (Nucletron BV®, Veenendaal, Netherlands) was used: IBU (integrated brachytherapy unit), PLATO or Oncentra planning system, and microselectron PDR with Iridium-192 sources used for treatment delivery. PDR-BT was chosen as a method that combines physical advantages of high-dose-rate (HDR) BT (isodose optimization, planning flexibility, and radiation safety) with radiobiological advantages of low-dose-rate (LDR) BT (repair advantages).

All flaps were monitored every $2 \mathrm{~h}$ for the first 3 days after surgery, every $6 \mathrm{~h}$ for 14-28 days directly after BT, and then every month during follow-up visits. Tissue color, turgor, temperature, capillary refill, and bleeding were estimated and noted (Table 1).

\section{Results}

In the study group, there were no hematomas, flap infections, or wound breakdowns resulting in fistulas. Four flaps had a favorable outcome - no monitor abnormalities were noted. In one case, peripheral skin necrosis was noticed. It appeared 7 days after surgery and 2 days after BT. It was free radial forearm flap used for the reconstruction of the stomal region. No revision surgery was needed but only surgical debridement of the necrotic margins. The wound healed by granulation. In one case, the signs of venous thrombosis appeared $12 \mathrm{~h}$ after surgery. Revision surgery revealed thrombus in the anastomosis. It was removed, and new venous anastomosis was created. The free thigh flap survived. There were no abnormalities noted after BT and in the follow-up time after referral (Table 1).
In the analyzed group, there were no serious wound and flap complications after BT. All wounds healed within 14 days after surgery as well as donor sites which healed within 4 weeks.

In the supplementary material, figures presenting following stages of one patient's treatment are presented.

\section{Discussion}

Surgical salvage is advocated as the best treatment option in terms of survival and locoregional control in patients with resectable recurrence in irradiated head and neck field [10]. As recurrent disease is typically multifocal and infiltrative, which can be undetectable in imaging or intraoperative view, it is worth to consider adjuvant tools to improve the oncological outcomes, especially in cases of uncertain margins. BT, as the method that allows the delivery of irradiation to the area where EBRT could be related to the high risk of complications and morbidity, should be placed into the treatment schemes in such cases [11-13].

The question posted in the paper concerned the feasibility of BT in tissues reconstructed with pedicle or free flaps and its potential to increase the risk of flap necrosis.

Flap survival depends on sufficient tissue perfusion. Postoperative circulatory failure requiring revision surgery and restoration of anastomosis patency still occurs in up to $28 \%$ of patients even in the most experienced hands [14, 15]. Soft tissue necrosis concerns 2 to $45 \%$ of patients treated with BT. It is noted more often in HDR (5-45\%) than in PDR (2-13\%) method [16-18]. In our material in one patient, peripheral necrosis of the flap was noticed. However, that distal ischemia was probably caused by incorrect reconstruction planning: too large flap in relation to feeding vessels.

In the literature, contrary data is presented concerning wound healing complication rates experienced by patients with head and neck tumors undergoing surgery with flap reconstruction followed by intraoperative or postoperative BT.

Ross et al. [19] documented the higher risk of wound complications in head and neck cancer patients treated with salvage surgery, microsurgical free flap reconstruction, and intraoperative BT (IOBT) compared with the non-IOBT group $(p<0.01)$. An overall complication rate of $38.33 \%$ was noticed in cases with an implanted bed as compared with $15.87 \%$ when IOBT was not used. The most common complication in the IOBT patients was wound dehiscence (11/60 patients; $18.33 \%$ ) followed by delayed complications like carotid exposure/rupture and osteoradionecrosis (which were seen in $11.67 \%$ of patients each).

A very high complication rate for IOBT was also presented by Geiger et al. [20]. In the group of 93 patients with head and neck cancers treated with IOBT, $94 \%$ with a prior history of RT, $51.6 \%$ experienced flap complications, the most common 
of which was flap dehiscence (32\% of patients). The risk of developing any type of flap complication was significantly higher when mandibular plates were used (odds ratio, 3.7; $p=0.009$ ). In another publication, Geiger et al. [21] compared complication rates between 55 pedicle flaps and 50 free flaps used for covering IOBT implants placed after head and neck tumor resection. An overall complication rate of $68 \%$ was noted in free flap reconstructions while $36.4 \%$ in pedicle flaps $(\mathrm{OR}=2.9, p=0.037)$. Moreover, in free flap reconstruction with IOBT, the need for operative revision was significantly higher than in pedicle flap group $(\mathrm{OR}=3.5, p=0.048)$. The authors conclude that the improved outcomes associated with pedicle flap reconstruction are related to the comparatively increased muscle bulk of pedicle flaps compared with most free flaps.

Conversely, Moscoso et al. [22] noticed no significant complications in the group of 15 patients with advanced recurrent head and neck cancers who underwent surgical resection followed by implantation of the tumor bed with Iridium192 after-loading catheters (13 patients) or Iodine-125 seeds (two patients) and coverage of the implanted area with regional myocutaneous flaps (10 patients) and microvascular free flaps (5 patients). An overall complication rate of $33 \%$ was reported. The authors did not notice flap necrosis. In one patient, after reconstruction of posterior pharyngeal wall defect with a radial forearm, a fistula appeared.

Panchal et al. [23] also concluded that interstitial BT can be delivered in the early postoperative period following free flap reconstruction without an increase in the frequency of wound breakdown. In 9 out of 10 patients treated with wide excision of soft tissue sarcomas and head and neck carcinomas followed by microvascular free flap reconstruction and BT with Iridium-192 wires, the wounds healed uneventfully. According to some authors, such good results were determined by delayed BT (it was administered 1 to 4 weeks postoperatively) which could have increased wound strength [20].

Schiefke et al. [24] also did not observe important problems neither in the microvascular free flaps nor in the pedicle flap used to reconstruct tissue defect and cover BT applicators in the group of 13 patients with recurrent, previously irradiated head and neck cancers treated with curative approach by tumor resection and HDR-BT. All flaps healed successfully, and there was no flap loss. Only minor surgical procedures were needed in 2 patients. The authors conclude that shortterm irradiation of the flap prior to the establishment of collateral blood flow does not adversely affect wound healing and flap survival. On the other hand, microvascular defect reconstruction is necessary because it provides sufficient soft tissue cover for BT. The same experience emphasizing the role of covering BT catheters with flaps which decreases the risk of complications was presented by Stafford and Dearnaley [25] and Cornes et al. [26].
In the literature, the wide variability of data concerning the influence of BT for wound healing and flaps vitality in patients with recurrent head and neck cancers can be found. Such visible discrepancy in presented results may partly be due to the variety of cases included into the studies, the diversity of treatment schemes used, the potential impact of other risk factors affecting proper healing, as well as the heterogeneity of BT application. The incidence of pedicle and free flap complications associated with IOBT reported in the literature is higher than in postoperative BT. Further investigations should be undertaken to explore this field. We are aware of the limitations of our study (small and heterogeneous group), so we state conclusions very carefully. Therefore, our preliminary results are promising, and we intend to include BT in treatment schemes in a larger group of our patients.

\section{Conclusions}

Based upon our data, pulsed-dose-rate brachytherapy seems to be a safe option that can be performed at the site of reconstruction in immediate postoperative period with minimal wound complications and with no impact on flap survival. Certainly, further clinical study based on larger patient series is needed to present statistically proven results.

Acknowledgments We thank $\uparrow$ Prof Janusz Skowronek and his team from the Brachytherapy Clinic of the Greater Poland Cancer Centre for preparing data summary of BT treatment of patients involved in the study.

\section{Compliance with Ethical Standards}

Conflict of Interest The authors declare that they have no conflict of interest.

Ethics Approval The protocol of the investigation has been approved by the Institutional Review Board of the Poznan University of Medical Sciences.

Open Access This article is licensed under a Creative Commons Attribution 4.0 International License, which permits use, sharing, adaptation, distribution and reproduction in any medium or format, as long as you give appropriate credit to the original author(s) and the source, provide a link to the Creative Commons licence, and indicate if changes were made. The images or other third party material in this article are included in the article's Creative Commons licence, unless indicated otherwise in a credit line to the material. If material is not included in the article's Creative Commons licence and your intended use is not permitted by statutory regulation or exceeds the permitted use, you will need to obtain permission directly from the copyright holder. To view a copy of this licence, visit http://creativecommons.org/licenses/by/4.0/.

\section{References}

1. Kim AJ, Suh JD, Sercarz JA, Abemayor E, Head C, Funk G, Blackwell KE (2007) Salvage surgery with free flap reconstruction: 
factors affecting outcome after treatment of recurrent head and neck squamous carcinoma. Laryngoscope. 117:1019-1023

2. Chang EI, Zhang H, Liu J, Yu P, Skoracki RJ, Hanasono MM (2016) Analysis of risk factors for flap loss and salvage in free flap head and neck reconstruction. Head Neck. 38(Suppl 1):E771-E775

3. Kim H, Jeong WJ, Ahn SH (2015) Results of free flap reconstruction after ablative surgery in the head and neck. Clin Exp Otorhinolaryngol 8:167-173

4. Ho AS, Kraus DH, Ganly I, Lee NY, Shah JP, Morris LG (2014) Decision making in the management of recurrent head and neck cancer. Head Neck 36:144-151

5. Kovács G (2014) Modern head and neck brachytherapy: from radium towards intensity modulated interventional brachytherapy. $\mathrm{J}$ Contemp Brachytherapy 6(4):404-416

6. Wierzbicka M, Bartochowska A, Strnad V, Strojan P, Mendenhall WM, Harrison LB, Rinaldo A, Sahai P, Wiegand S, Ferlito A (2016) The role of brachytherapy in the treatment of squamous cell carcinoma of the head and neck. Eur Arch Otorhinolaryngol 273: 269-276

7. Lee MK, Blackwell KE, Kim B, Nabili V (2013) Feasibility of microvascular head and neck reconstruction in the setting of calcified arteriosclerosis of the vascular pedicle. JAMA Facial Plast Surg 15:135-140

8. Finical SJ, Doubek WG, Yugueros JCH (2001) The fate of free flaps used to reconstruct defects in recurrent head and neck cancers. Plast Reconstr Surg 107:1363-1366

9. Schultze-Mosgau S, Grabenbauer GG, Radespiel-Tröger M et al (2002) Vascularization in the transition area between free grafted soft tissues and pre-irradiated graft bed tissues following preoperative radiotherapy in the head and neck region. Head Neck 24:42-51

10. Arnold DJ, Goodwin WJ, Weed DT, Civantos FJ (2004) Treatment of recurrent and advanced stage squamous cell carcinoma of the head and neck. Semin Radiat Oncol 14:190-195

11. Bartochowska A, Skowronek J, Wierzbicka M, Leszczynska M, Szyfter W (2013) High-dose-rate and pulsed-dose-rate brachytherapy in the management of recurrent or residual stomal tumor after total laryngectomy. Laryngoscope. 123:657-661

12. Polo A (2009) High-dose-rate and pulsed-dose-rate brachytherapy for oral cavity cancer and oropharynx cancer. J Contemp Brachyther 1(4):216-223

13. Mazeron JJ, Ardiet JM, Haie-Méder C, Kovács G, Levendag P, Peiffert D, Polo A, Rovirosa A, Strnad V (2009) GEC-ESTRO recommendations for brachytherapy for head and neck squamous cell carcinomas. Radiother Oncol 91:150-156

14. Schrey AR, Kinnunen IA, Grénman RA, Minn HR, Aitasalo KM (2008) Monitoring microvascular free flaps with tissue oxygen measurement and PET. Eur Arch Otorhinolaryngol 265(Suppl 1): S105-S113

15. Seaber AV (1987) Experimental vasospasm. Microsurgery 8:234-241
16. Fujita M, Hirokawa Y, Kashiwado K, Akagi Y, Kashimoto K, Kiriu H, Matsuura K, Ito K (1999) Interstitial brachytherapy for stage I and II squamous cell carcinoma of the oral tongue: factors influencing local control and soft tissue complications. Int J Radiat Oncol Biol Phys 44:767-775

17. Kakimoto N, Inoue T, Inoue T, Murakami S, Furukawa S, Yoshida K, Yoshioka Y, Yamazaki H, Tanaka E, Shimizutani K (2006) High-dose-rate interstitial brachytherapy for mobile tongue cancer: influence of the non-irradiated period. Anticancer Res 26:39333937

18. Strnad V, Geiger M, Lotter M, Sauer R (2003) The role of pulseddose-rate brachytherapy in previously irradiated head-and-neck cancer. Brachytherapy. 2:158-163

19. Ross DA, Hundal JS, Son YH, Ariyan S, Shin J, Lowlicht R, Sasaki CT (2004) Microsurgical free flap reconstruction outcomes in head and neck cancer patients after surgical extirpation and intraoperative brachytherapy. Laryngoscope. 114:1170-1176

20. Geiger EJ, Basques BA, Chang CC, Alcon AW, Narayan D (2014) Wound healing complications with intraoperative brachytherapy for head and neck cancer: a unique form of radiation injury. Ann Plast Surg 73:378-384

21. Geiger EJ, Basques BA, Chang CC, Son Y, Sasaki CT, McGregor A, Ariyan S, Narayan D (2016) Pedicle versus free flap reconstruction in patients receiving intraoperative brachytherapy. J Plast Surg Hand Surg 50:227-322

22. Moscoso JF, Urken ML, Dalton J, Wesson MF, Biller HF (1994) Simultaneous interstitial radiotherapy with regional or free flap reconstruction, following salvage surgery of recurrent head and neck carcinoma. Analysis of complications. Arch Otolaryngol Head Neck Surg 120:965-972

23. Panchal JI, Agrawal RK, McLean NR, Dawes PJ (1993) Early postoperative brachytherapy following free flap reconstruction. $\mathrm{Br}$ J Plast Surg 46:511-515

24. Schiefke F, Hildebrandt G, Pohlmann S, Heinicke F, Hemprich A, Frerich B (2008) Combination of surgical resection and HDRbrachytherapy in patients with recurrent or advanced head and neck carcinomas. J Craniomaxillofac Surg 36:285-292

25. Stafford N, Dearnaley D (1988) Treatment of 'inoperable' neck nodes using surgical clearance and postoperative interstitial irradiation. Br J Surg 75:62-64

26. Cornes PG, Cox HJ, Rhys-Evans PR, Breach NM, Henk JM (1996) Salvage treatment for inoperable neck nodes in head and neck cancer using combined iridium-192 brachytherapy and surgical reconstruction. Br J Surg 83:1620-1622

Publisher's Note Springer Nature remains neutral with regard to jurisdictional claims in published maps and institutional affiliations. 